\title{
Nitrogen use efficiency and yield in response graft bell pepper cultivars
}

\author{
Mónica Liliana Garcia-Bañuelos', Esteban Sanchez ${ }^{1 *}$, Alfonso Antero Gardea-Béjar², \\ Ezequiel Muñoz-Marquez', Juan Manuel Soto-Parra ${ }^{3}$, Damaris Leopoldina Ojeda-Barrios ${ }^{3}$,
}

${ }^{1}$ Centro de Investigación en Alimentación y Desarrollo, A.C. Unidad Delicias, Avenida Cuarta Sur, Fraccionamiento Vencedores del Desierto. Cd. Delicias, Chihuahua, C.P, México, ${ }^{2}$ Centro de Investigación en Alimentación y Desarrollo, A.C. Carretera a la Victoria Km 0.6, Hermosillo, Sonora. México, ${ }^{3}$ Facultad de Ciencias Agrotecnológicas. Universidad Autónoma de Chihuahua. Ciudad Universitaria S/N Campus 1, Chihuahua, Chihuahua. México

\section{A B S TR A C T}

In this investigation, characterize of the efficient use of nitrogen (EUN) through of the analyses of key biochemical and physiological indicators involved in $\mathrm{NO}_{3}$ - reduction and fruit production of Capsicum annuum L. taking advantage of the cultivar/rootstock relationship, were evaluated through crop cycle 2013. The combinations were: Orangela/Terrano (O/T), Janette/Terrano (J/T), Fascinato/Terrano $(F / T)$, Fascinato/Robusto (F/R), Sweet/Robusto (S/R). The horticultural crop were under agriculture net and harvested on three specifics sampling dates. The results showed statistical differences $(p \leq 0.05)$ in grafted cultivars for EUN and yield. The greatest $\mathrm{N}$ assimilation was presented with the combination Fascinato/Robusto, which coincided with the maximum yield of all cultivar/roostock combinations evaluated. Hence grafting bell pepper plants has been used per decades as a quick, ecological and effective technique to improve EUN, which has beneficial implications to mitige the severe contamination of vital natural resources and a sustained and healthy crop production.

Keywords: Capsicum annuum; Graft; Greenhouse; Nitrogen pathway; Rootstocks

\section{INTRODUCTION}

In Mexico, bell pepper (Capsicum annum L.) is a vegetable with high demand worldwide that the farmers produce in open fields and greenhouse. Some varieties that are regularly grown in Mexico for fresh consumption in the domestic market and mainly for export are demanded for their appearance, high quality and delicious taste (De Charlo et al., 2012). The interest in the consumption of colored pepper is, to a large extent, due to its content of bioactive compounds (Chávez et al., 2013). Bell peppers are a rich source of antioxidants than can varied among the genotypes (red, yellow, orange, green, chocolate/brown, vanilla/white, and purple), at both the mature and whole ripened stages (Chávez et al., 2015). These antioxidant phytochemicals have scientifically proven abilities to prevent some types of cancers, they also have an effect in the control of cardiovascular diseases, atherosclerosis, and they influence positively preventing the aging's process (Selahle et al., 2015).

In plant growth, $\mathrm{N}$ is the most important essential element, which also has greater complexity within the potential physiological processes in which it is involved. However, several studies carried out around the world and in different environments, have shown that between 50 and $70 \%$ of the total $\mathrm{N}$ applied to the soil, is lost as a result of runoff, denitrification, volatilization and leaching (Montemurro and Diacono, 2016). This macroelement, is considered a potential environmental contaminant, and therefore, the efficiency (NUE) of its rational use, is fundamental for agricultural sustainability and natural environmental conservation (Yasuor et al., 2013; Mascleaux-Daubresse et al., 2010). Care in the application of nitrogen fertilizers in crops, has become a priority in recent years, due to the worrying increase in nitrate $\left(\mathrm{NO}_{3}-\mathrm{N}\right)$ concentrations in groundwater, which have been associated with the excessive application of these Fertilizers in agriculture (Del Amor, 2007; Yasuor et al., 2013).

The technique of plant grafting is practiced today in many regions around the world, in crops such as pepper, tomato, cucumber, watermelon, melon and eggplant which have been and continue to be cultivated in the open field, agricultural nets and greenhouses (Lee et al.,

\footnotetext{
${ }^{*}$ Corresponding author:

Esteban Sánchez, Centro de Investigación en Alimentación y Desarrollo A.C. Unidad Delicias. Av. Cuarta Sur 3820, Fracc. Vencedores del Desierto. Cd. Delicias, Chihuahua. México. C.P. 33089. E-mail: esteban@ciad.mx
}

Received: 21 September 2016; Revised: 27 April 2017; Accepted: 30 April 2017; Published Online: 13 May 2017 
2010; Djidonou et al., 2013). For decades, the rootstock has been used to provide resistance to plants against rising and falling temperatures (Rivero et al., 2003; Venema et al., 2008), is a good tool used to facilitate the ansortion of available mineral nutrient of the soil solution (Leonardi and Giuffrida, 2006), increase levels and synthesis of hormones (Dong et al., 2008), strengthens the crops so that they are able to develop in salinity conditions (Colla et al., 2010), improves the processes of the plant that help to make the use of water more efficient (Rouphael et al., 2008a), decrease uptake of persistent organic pollutant (COPs) or toxic chemical resistant compounds from cultivable soils (Otani and Seike, 2007), helps tolerate overwatering and waterlogging (Yetisir et al., 2006), improves the caracteristics of the fruit that give it greater commercial value (Proietti et al., 2008), and minimize the toxic effects as a result of high concentrations of copper, cadmium and boron (Savvas et al., 2009; Arao et al., 2008). Nevertheless, there is little published scientific information worldwide about the efficiency of nitrogen in crops that have been grafted (Djidonou et al., 2013; Du et al., 2016). In 2006, Ruiz and collaborators experimented with the efficiency of the use of $\mathrm{N}$ to study their trait in tobacco plants, could observe that the graft was defined as an effective, fast and viable alternative to increase the efficiency in the use of this main nutrient stimulating the assimilation of nitrates, unlike not grafted plants. In research carried out by Colla and collaborators in 2010 and 2011, mentioned that the grafting of mini-plants of watermelon in the selected rootstocks, are an effective way that improves the fruit production and efficient the use of $\mathrm{N}$.

In general, there is little literature available on the influence of the rootstock on the efficient use of nitrogen in bell pepper. So that, the aim of this research was to measure the effect of Terrano and Robusto rootstocks on the nitrogen assimilation of commercial varieties of bell pepper, and to make a selection of the grafted plants that showed the highest level of sassimilation and efficiency in the use of $\mathrm{N}$.

\section{MATERIALS AND METHODS}

\section{Location, greenhouse condition and plant material}

The experiment was carried out at "Los Alamos", a private greenhouse located in northern Mexico (Delicias, Chihuahua; $28^{\circ} 11^{\prime} \mathrm{N}$ and $105^{\circ} 28^{\prime} \mathrm{W}, 1170 \mathrm{masl}$ ), and in the production cycle 2013. In this region the climate is semi-arid with very hot days and warm nights during all the summer, the rainfall is moderate and with thunderstorms. During the winter, there are warm days with cold nights and rainfall is scarce. As a result, the Delicias region has 50 days of average rainfall, with seven months a year frost free, and $45 \%$ average relative humidity.
Because of the above conditions this commercial greenhouse is equipped with photo-selective nets or shading screens to improved bell pepper yields (Basile et al., 2012). In this study, commercial white nets (Euro S.A. de C.V., Mexico City, MX) were placed horizontally over the crop at $3 \mathrm{~m}$ above ground. Its spectral properties corresponded to $38 \%$ shading over the entire sunlight radiation.

The plant material studied was five bell pepper cultivars: 'Jannette' (yellow fruit), 'Fascinato' (red fruit), 'Orangela' (orange fruit), and 'Sweet' (green fruit) (Syngenta Seed, Houston, TX, USA). These cultivars were grafted onto Terrano and Robusto, a commercial rootstock (Syngenta Seed, Houston, TX, USA) which have shown good resistance to the Phytophthora capsici attack, which causes the disease commonly known as "quick wilt". Both scion and rootstock were seeded and grown under greenhouse conditions. Seeds were germinated in January 2013 and the different varieties were grafted using the cleft grafting technique 31 days after sowing (Lee and Oda, 2002). This involves contacting rootstock and variety tissues, so than their cambium regions coincide and remain closely linked by pressing a silicone graft clip. This resulted in combinations of scions and rootstock.

At complete 45 days of grafting, the plants were transplanted to beds in the commercial photoselective white agricultural net, previously described.

Based on soil's analysis, it was observed that the plants were grown in a ground with clay, silt and sand percentages of $29.84,12.08$ and $57.36 \%$ respectively, classifying it in a sandy-clay soil, in addition, the organic nitrogen content with a value of $50.17 \mathrm{ppm}$ was quantified, soil phosphorus with $64.14 \mathrm{ppm}$, other parameters obtained as 1.68\% in MO, 7.72 in $\mathrm{pH}, 32.5 \mathrm{me} / 100 \mathrm{~g}$ of CIC and $0.84 \mathrm{ds} / \mathrm{m}$ of EC. The furrow and plants orientation was north-south and T-bar. The greenhouse was divided into five experimental plots, corresponding to five treatments. The surface of the selected blocks was $2565 \mathrm{~m}^{2}$ (5 130 plants), corresponding to 19 rows of 270 plants. The plants were spaced $30 \mathrm{~cm}$ between them.

The cultural practices of crop management were carried out as indicated by the production company, following the protocols used in previous years. The products applied for the nutrition of the crop were: UAN32 (37.7 g.m $\left.{ }^{2}\right), \mathrm{NH}_{4} \mathrm{NO}_{3}\left(50.4\right.$ g.m $\left.{ }^{2}\right), 5-30-00$ (N-P-K) $\left(56\right.$ g.m $\left.{ }^{2}\right), \mathrm{Ca}\left(\mathrm{NO}_{3}\right)_{2}\left(162.3 \mathrm{~g} \cdot \mathrm{m}^{2}\right), \mathrm{KNO}_{3}\left(44.8 \mathrm{~g} \cdot \mathrm{m}^{2}\right), \mathrm{K}_{2} \mathrm{SO}_{4}$ (201.3 g.m²), and $\mathrm{MgSO}_{4}\left(107.5 \mathrm{~g} \cdot \mathrm{m}^{2}\right)$. The crop cycle ended on August 2012, after 5 harvests.

\section{Experimental design}

The complete life cycle of all evaluated plants was in the same photoselective white agricultural net. The 
experimental design used for all treatments was a complete randomized block with five replicates: 'Jannette'/ 'Terrano' (J/T), 'Orangela'/'Terrano' (O/T), 'Fascinato'/'Terrano' (F/T), 'Fascinato'/'Robusto' (F/R) and 'Sweet'/'Robusto' $(\mathrm{S} / \mathrm{R})$ and five blocks. Each block accounted for 5130 plants (with a surface of $2565 \mathrm{~m}^{2}$ ), but the evaluations of all cultivars were performed only on the central rows to avoid the effect of mixed light.

\section{Plant sampling}

For measurements of physiological and biochemical variables, 10 plants were taken from the central grooves of each block. Fruits and leaves were sampled from these 10 plants and they were considered as the experimental unit. Seasonal variation was evaluated during the months of fruit production, for this propose samples were taken monthly (from July to September). When fruits reached these maturity standards, leaves and fruits were collected from each plant and they were used for evaluation of physiological and biochemical variables. Every 30 days, throughout full fruit production period, three mature and well developed leaves were collected from the middle of the stem of each plant. Leaf samples taken were only from plants with fully expanded leaves of similar size. Fruit samples were harvested to mature, with acceptable color, size and firmness, this matter was used for yield analysis. Leaves and fruits were stored in an icebox at $4^{\circ} \mathrm{C}$ and immediately transported to the laboratory. There, the material was washed with tap, distilled and finally deionized water, and placed on brown paper to remove the water excessive.

Each leaves sample was separated in two subsamples. One subsample was stored at $4^{\circ} \mathrm{C}$, and this leaf fresh tissue was used for NR enzymatic assay, as well as chlorophyll analyses. The other was dried inside an oven at $70^{\circ} \mathrm{C}$ for 24 hours and then ground in a common blender, this dry material was placed in plastic bags for further analysis of total nitrogen in leaf tissue.

\section{Agronomic variables}

Plant growth. It was determined by measuring the height of each bell pepper plant (10 plants), according to ResendizMelgar et al. (2010). Plant length was monitored monthly, during the 2013 fruit production period. This parameter was expressed as the mean in centimeters of three plants (cm per plant).

Crop yield. It was determined by counting and weighing all fruits harvested on each plant, according to SánchezChávez et al. (2011). This parameter was expressed as the mean of fruit weight (Kg per plant). Peppers were harvested at the mature stage, according to the same maturity indexes of the Mexico Supreme Quality Standards
(Mexico Calidad Suprema, 2012). The fruits harvested were classified into two categories, marketable for export and marketable for the national market, later weighed. What was taken as total yield, was the sum of the two weights.

\section{Biochemical variables}

Nitrate reductase (NR) assays. Leaf fresh matter was used for in vivo NR (E.C. 1.6.6.1.) activity, using the methodology proposed by Ruiz and Romero (1999). A metal borer ( $5 \mathrm{~mm}$ of diameter) was use to remove disks of each leaf, about $0.125 \mathrm{~g}$, once this is done, each samples was weighed and placed in $10 \mathrm{~mL}$ of incubation buffer (100 mM of K-phosphate buffer to $7.5 \mathrm{pH}$, containing 1\% of propanol). Samples were vacuum-infiltrated ( $0.8 \mathrm{bar})$ by $10 \mathrm{~min}$, to flush buffer into tissue intracellular spaces. Enzymatic assay was performed at $30^{\circ} \mathrm{C}$ in darkness for $1 \mathrm{~h}$. Immediately, this reaction was stopped by incubation at $100^{\circ} \mathrm{C}$ during $15 \mathrm{~min}$. The resulting product of reaction $\left(\mathrm{NO}_{2}{ }^{-}\right)$was spectrophotometrically quantified at $540 \mathrm{~nm}$, in a reaction mixture containing $1 \mathrm{ml}$ of enzymatic assay extract, $2 \mathrm{ml} 1 \%$ of sulfanilamide and $2 \mathrm{ml} 0.02 \%$ of N-NEDA (N-1-naphthyl-ethylenediamine). The results of the NR activity were reported in micromoles of $\mathrm{NO}_{2}^{-}$per gram of fresh weight per hour ( $\mu$ g of $\mathrm{NO}_{2}^{-} \mathrm{g}^{-1}$ of fw $\left.\mathrm{h}^{-1}\right)$.

For each sample, two reactions were made aiming to obtain the endogen NR activity (without $\mathrm{NO}_{3}{ }^{-}$) and $\mathrm{NR}$ activity induced by $\mathrm{NO}_{3}^{-}$. The $\mathrm{NR}$ activity induced by $\mathrm{NO}_{3}^{-}\left(\mathrm{NR}+\mathrm{NO}_{3}^{-}\right)$was determined following the steps of the same method, but using a modified incubation buffer, containing $50 \mathrm{mM}$ of $\mathrm{KNO}_{3}$.

\section{Physiologic variables}

Relative leaf chlorophyll content. Leaf chlorophyll contents were nondestructively quantified with a Konica-Minolta SPAD-502 chlorophyll meter (Minolta Camera CO, LTD., JPN), according to chlorophyll meter operation manual (Ling et al., 2011). Young fully-expanded leaves of pepper plants were analyzed in each plot. Measurements were taken at mid canopy, on single, healthy, fully expanded leaves, four to five nodes from the branch apex. SPAD measurements were taken 20 times on the surface of each leaf, and averaged per leaf was recorded. Relative leaf chlorophyll (Chl) was expressed as SPAD units. SPAD units are values defined by Konica Minolta indicating the relative amount of chlorophyll present in plant leaves.

Leaf chlorophyll analysis. Total chlorophyll (Chl: a + b) extraction from fresh foliage followed methods outlined by Wellburn (1994) and García et al. (2002). Young fully expanded leaves were used for this analysis. A cork borer ( $7 \mathrm{~mm}$ of diameter) was used to removed leaf disks from each leaf. Disks were weighed (0.125 g) and placed in sealed test tubes. Chlorophyll pigments 
were extracted by incubating leaf disks in $10 \mathrm{ml}$ of methanol in the dark at room temperature, for $24 \mathrm{~h}$. For Chl quantification, theses extracts were assayed with a spectrophotometer at two wavelengths (666 and $653 \mathrm{~nm})$. Data $(\mathrm{Chl} \mathrm{a}+\mathrm{b})$ were expressed as micrograms of chlorophyll per square centimeter, using Wellburn equations: $\mathrm{Chl} \mathrm{a}=[15.65(\mathrm{~A} 666)-7.34(\mathrm{~A} 653)]$ and $\mathrm{Chl} \mathrm{b}=$ [27.05(A653)-11.21(A666)]. Results of leaf total Chl were expressed as $\mathrm{mg} \mathrm{cm}^{-2}$.

Leaf nitrogen analysis. Dried leaf material was exposed to sulfuric mineralization to measure total $\mathrm{N}$ by a modified version of the micro-Kjeldahl method (Association of Official Analytical Chemist, 1990; Baker and Thompson, 1992; Chang, 1998). Total leaf dry weight (DW) was determined by drying in an oven at $60^{\circ} \mathrm{C}$ until constant weight. $0.1 \mathrm{~g}$ of the sample were accurately weighed, following digestion with $5 \mathrm{~mL}$ of concentrated sulfuric acid (JT Baker ACS) in the presence of a catalyst by using a Labconco Digestion System (Labconco, Kansas City, MO). The catalyst was a Selenium reagent mixture $(1.45 \%$ copper sulfate, $1.5 \%$ selenium and sodium sulfate $94 \%$ ). The method used $50 \% \mathrm{NaOH}$ to produce an alkaline distillation and a $6 \mathrm{~mL}$ of $4 \%$ boric acid and Wessowl $0.2 \%$ reagent solution to collect the distilled ammonia. The titrations were performed with standardized $0.1 \mathrm{~N}$ hydrochloric acid on a graduated burette. The $\mathrm{N}$ concentration was expressed as percent of total $\mathrm{N}$ of dried leaf tissue.

\section{Statistical analysis}

The obtained data were analyzed using statistical software SAS (SAS Institute Inc., USA) in a simple ANOVA with a confidence of $95 \%$. The means were compared using the LSD test $(\mathrm{P}=0.05)$. The data shown are mean values \pm standard error $(\mathrm{SE})$.

\section{RESULTS AND DISCUSSION}

\section{Yield}

We analyzed fruit yield of grafted bell pepper cultivars at full production, according to the Mexico Supreme Quality standard (Mexico Calidad Suprema, 2012). It found than fruit yield was significantly higher for 'Fascinato' cultivars compared with the rest of colored bell pepper cultivar studied. Fig. 1, shown then grafted 'Fascinato' cultivar $(\mathrm{F} / \mathrm{T})$ registered the largest fruit yield respect to all studied cultivars $(\mathrm{O} / \mathrm{T}, \mathrm{J} / \mathrm{T}, \mathrm{F} / \mathrm{R}$ and $\mathrm{S} / \mathrm{R})$. Therefore, these results indicated than $\mathrm{F} / \mathrm{T}$ cultivar was more efficient to obtain a high fruit yield, under these greenhouse conditions.

We demonstrated that grafting improves crop yield of bell pepper cultivars. The grafting showed its efficiency on fruit yield, since, in the majority of grafted plants, the fruits increased their weight. Its effect could be attributed to the interaction of processes of substantial increase in the absorption of water and essential nutrients, as a consequence of the rootstock's extended and vigorous root system and an enhancement of scion vigor. The joint action of these processes could explain the highest yield of grafted pepper plants, especially on 'Fascinato'- Terrano cultivar. The highest production of pepper fruit observed and derived from grafted plants, was also reported in similar pepper varieties (Del Amor et al., 2008; De Charlo et al., 2012; Yasuor et al., 2013).

\section{Vegetative growth}

The plant growth of grafted bell pepper cultivars was analyzed monthly, during three months of fruit production (July, August and September) of the year 2013. Plant length $(\mathrm{cm})$ of the studied varieties $(\mathrm{O} / \mathrm{T}, \mathrm{J} / \mathrm{T}, \mathrm{F} / \mathrm{T}, \mathrm{F} / \mathrm{R}$ and $\mathrm{S} / \mathrm{R})$ had a significant effect by the type of scion. In Fig. 2, we can see than the orange grafted genotype The rest of the grafted cultivar (J/T, F/T, F/R and S/R) did no shown a significate difference in this variable, indicating than the type of rootstock used ( $T$ and $R$ ) had not a significate affected in plant growth of theses bell pepper varieties;

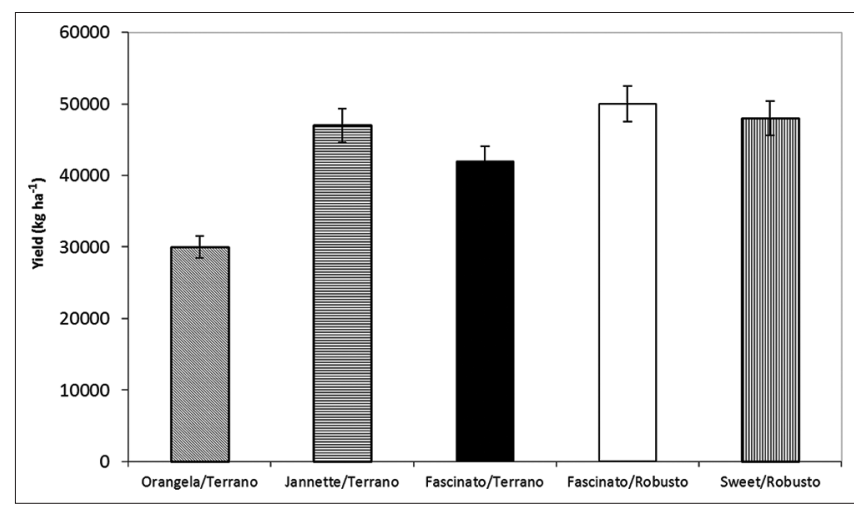

Fig 1. Effect of rootstock on fruit yield of bell pepper plants. 'Orangela'/'Terrano' (O/T), 'Fascinato/Robusto' (F/R), 'Fascinato'/'Terrano' (F/T), 'Janette'/'Terrano' (J/T) and 'Sweet'/'Robusto' $(\mathrm{S} / \mathrm{R})$. Data are means \pm standard error.

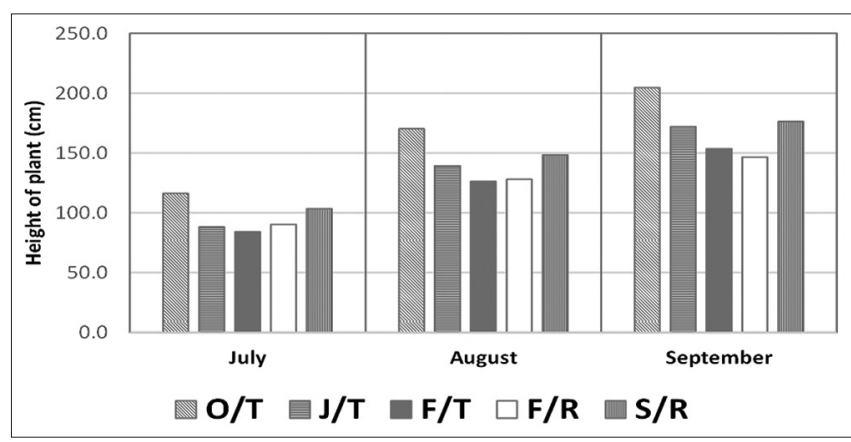

Fig 2. Effect of rootstock on plant grown (height of plants) during fruit development of bell pepper cultivars. 'Orangela'/'Terrano' $(\mathrm{O} / \mathrm{T})$, 'Janette'/'Terrano' (J/T), 'Fascinato'/'Terrano' (F/T), 'Fascinato/ Robusto' (F/R) and 'Sweet'/'Robusto' (S/R). Data are means. 
therefore, this result confirm the efficiency of grafting for the two rootstock, as reported in previous studies. This behavior can be better appreciate with 'Fascinato' genotype, which was grafted with these two rootstock ( $T$ and $R$ ). In Fig. 2, we can observed than both grafted cultivar (F/T and $\mathrm{F} / \mathrm{R}$ ) present similar values of height of the plants. The statistical analysis did no show significant differences in plant grown between $\mathrm{F} / \mathrm{T}$ and $\mathrm{F} / \mathrm{R}$ bell pepper cultivars, during this moths of fruit production. This confirm than both rootstocks had a high compatibility and adequate affinity with this orange variety of bell pepper. These results coincident with the reported by others authors, than the use of grafted plants improvement and increase yield of vegetables, such as bell pepper cultivars (Del Amor et al., 2008; Basile et al., 2012; De Charlo et al., 2012; Yasuor et al., 2013).

\section{Biochemical parameters}

Biochemical markers were analyzed during the months of fruit production (July, August and September). Fig. 3 shows the results of biochemical markers of $\mathrm{N}$ efficiency of the five grafted bell pepper cultivars $(\mathrm{O} / \mathrm{T}, \mathrm{J} / \mathrm{T}, \mathrm{F} / \mathrm{T}$, $\mathrm{F} / \mathrm{R}$ and $\mathrm{S} / \mathrm{R})$. These dates correspond to two enzymatic activities of in vivo nitrate reductase (NR) analyzed in leaf tissue: NR induced by nitrate (A) and NR endogen (B).

This variable also had a significant effect by the type of scion utilized ('Orangela' 'Fascinato', 'Jannette' and 'Sweet'). We found than the varieties with a remarkable behavior in

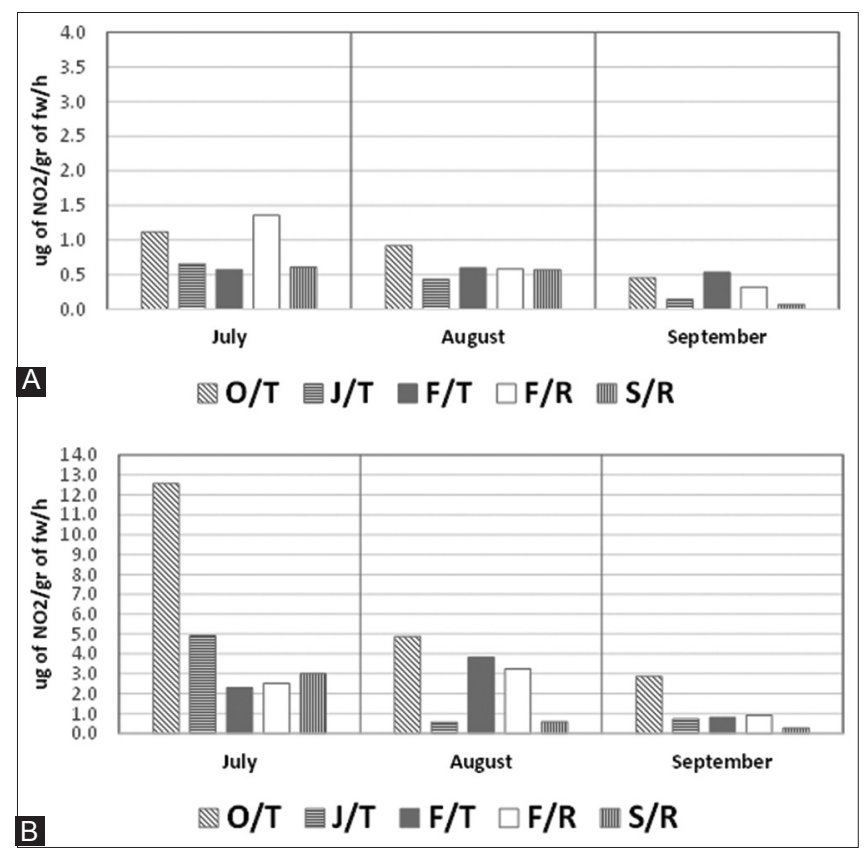

Fig 3. Effect of rootstock on in vivo NR activity in leaves of bell pepper plants. Two reactions of in vivo NR: (A) endogen NO3 and (B) induced by NO3. 'Orangela'/'Terrano' (O/T), 'Janette'/'Terrano' (J/T), 'Fascinato'/'Terrano' (F/T), 'Fascinato/Robusto' (F/R) and 'Sweet'/'Robusto' (S/R). Data are means. their NR enzymatic activity were 'Orangela' and 'Fascinato'. While the grafted orange variety $(\mathrm{O} / \mathrm{T})$ had the highest $\mathrm{NR}$ activity with respect to than the rest of the grafted varieties studied, the red variety $(\mathrm{F} / \mathrm{T}$ and $(\mathrm{F} / \mathrm{R})$ showed a significant increase in the enzyme activity in the second month analyzed (August), which is an indicator of $\mathrm{N}$ metabolism more active.

In Fig. 3, Panel a, we can observed than the NR enzymatic activity of 'Orangela' had the next behavior throughout the crop cycle: At the first stages of fruit production (July) the grafted orange cultivar $(\mathrm{O} / \mathrm{T})$ had the highest $\mathrm{NR}$ activity than the rest grafted varieties $(\mathrm{p} \leq 0.05)$. However, these $\mathrm{NR}$ activity of $\mathrm{O} / \mathrm{T}$ plants had a significant decreased during the next months of fruit production (August and September). It is important to mention than this grafted cultivar always registered the highest $\mathrm{NR}$ activity than the other plants combinations $(\mathrm{J} / \mathrm{T}, \mathrm{F} / \mathrm{T}, \mathrm{F} / \mathrm{R}$ and $\mathrm{S} / \mathrm{R})$, during the three moths studied $(\mathrm{p} \leq 0.05)$. In contrast, the behavior throughout the crop cycle of the NR enzymatic activity for 'Fascinato' was as follows (Fig. 3, Panel A): At the first stages of fruit production (July) the two red grafted cultivars (F/T and F/R) had a low NR activity, compared with the other grafted varieties $(\mathrm{O} / \mathrm{T}, \mathrm{J} / \mathrm{T}$ and $\mathrm{S} / \mathrm{R})(\mathrm{p} \leq \mathrm{0.05})$. However, at later stages of the crop cycle (August and September), the NR activity of these grafted plants had a significant increased during these next two months of fruit production studied $(\mathrm{p} \leq 0.05)$. These results could support the issue than grafted 'Fascinato' variety $(\mathrm{F} / \mathrm{T}$ and $\mathrm{F} / \mathrm{R})$ has more efficient use of $\mathrm{N}$ than the rest of grafted genotypes studied $(\mathrm{O} / \mathrm{T}, \mathrm{J} / \mathrm{T}$ and $\mathrm{S} / \mathrm{R})$. It is probably, than this condition helped to obtain a high fruit yield under these greenhouse conditions. This fact agreed with the notorious previous scientifics research about the use of rootstocks in vegetables and bell pepper cultivars (Del Amor et al., 2008; De Charlo et al., 2012; Yasour et al., 2013).

Respect to NR endogen activity (Fig. 3, Panel B), 'Orangela' and 'Fascinato' were the two grafted genotypes than showed the highest values, with respect to the rest of genotypes studied ('Jannette' and 'Sweet'). NR endogen activity it is considered an indicator of leaf $\mathrm{NO}_{3}{ }^{-}$concentration, thus this condition of high endogen activity to allow a favorable $\mathrm{NO}_{3}$ - accumulation in leaf of these grafted cultivars; therefore, the $\mathrm{NO}_{3}{ }^{-}$bioavailable required for a more active N metabolism and fruit production (Pulgar et al., 2000; Ruiz et al., 2006). Apparently, the efficient use of $\mathrm{N}$ shown by these grafted bell pepper plants produced an increase of fruit yield, as reported by other studies (Del Amor et al., 2008; De Charlo et al., 2012; Yasuor et al., 2013).

Inside the plant, $\mathrm{N}$ is an irreplaceable and key in crop yield and quality. $\mathrm{NO}_{3}$ - is the main source of $\mathrm{N}$ for higher 
plants. The assimilation of $\mathrm{NO}_{3}^{-}$by the root's plants requires the reduction to $\mathrm{NO}_{2}^{-}$, the conversion of $\mathrm{NO}_{2}{ }^{-}$to $\mathrm{NH}_{4}^{+}$, and the incorporation of $\mathrm{NH}_{4}^{+}$into amino acids via glutamate synthase enzymatic cycle. The $\mathrm{NO}_{3}{ }^{-}$assimilation is catalyzed by $\mathrm{NR}$ to covert to ammonium $\left(\mathrm{NO}_{3}{ }^{-}\right.$to $\mathrm{NO}_{2}^{-}$). Leaf tissues accumulate $\mathrm{NO}_{3}^{-}$when the assimilation capacity of these tissues is exceeded. An increase in the amount and activity of $\mathrm{NR}$ it entails to a $\mathrm{NO}_{3}$ - reduction and confers a greater capacity for amino acid-protein synthesis and total $\mathrm{N}$ assimilation. Therefore, $\mathrm{NO}_{3}^{-}$level and NR activity are considered determinate factors for the growth and development of plants. In this study, we found a higher NR activity in leaves of grafted plants, reflecting the greater efficiency of reducing $\mathrm{NO}_{3}{ }^{-}$to $\mathrm{NO}_{2}$. The more efficient NR activity in grafted plants is related with the effect of rootstock on the uptake of nutrients. The low NR endogenous activity (indicator of a low leaf $\mathrm{NO}_{3}{ }^{-}$concentration) in grafted plants may be due to higher $\mathrm{NR}$, and thus a greater potential for reducing $\mathrm{NO}_{3}$ - (Pulgar et al., 2000; Ruiz et al., 2006).

Apparently, the efficient use of $\mathrm{N}$ shown by grafted pepper plants produced an increase of fruit yield, as reported by other studies (Del Amor et al., 2008; De Charlo et al., 2012; Yasuor et al., 2013). This relationship was clear and evident within the plants grafted with the two scions ('Fascinato' and 'Jannette'), particularly grafted 'Fascinato' cultivar $(\mathrm{F} / \mathrm{T})$. The main characteristic for the widespread use of grafted plants is the vigorous root system than present many rootstocks; this condition helps to absorb water and inorganic nutrients more efficiently. We found than the NR activity was significantly influenced by scion-rootstock action and by rootstock (Fig. 3, panel B). This favored the nitrates concentration, positively stimulating the nitrate reductase and nitrogen metabolisms in the grafted plants.

\section{Physiologic parameters}

We had demonstrate the improvement of leaf photosynthesis by thermal photoselective sheets technology to increase yields in grafted bell pepper crops, especially during the full fruit-growing stages. It is considered than appropriate shading not only improved plants fruit yield relative to plants in full sunlight (especially under drought stress), also improved pigment accumulation and density per unit leaf area to optimize the light absorption (Zhu et al., 2012; Dai et al., 2009; Wittmann et al., 2001).

In order to determinate the effect of thermal photoselective sheets technology in the colored grafted bell peppers, were evaluated physiological parameter involved in $\mathrm{N}$ and photosynthetic pathway during their fruit-growing stages, under one shade level (38\% of shade). Fig. 4, shows the chlorophyll concentration (Panel A) and relative leaf chlorophyll content (Panel B) analyzed in leaf tissue of

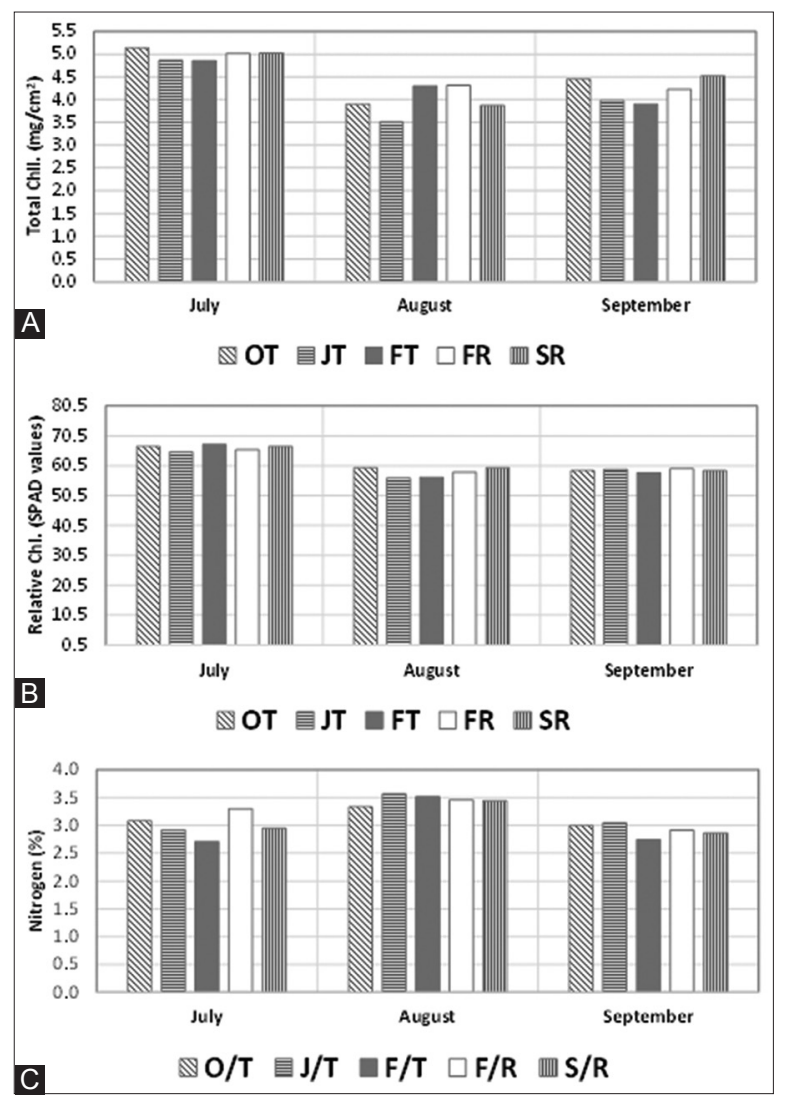

Fig 4. Effect of rootstock on photosynthetic pathway. Total chlorophyll $(A)$, relative leaf chlorophyll $(B)$ and nitrogen $(C)$ in leaves of bell pepper cultivars. Orangela'/'Terrano' (O/T), 'Janette'/'Terrano' $(\mathrm{J} / \mathrm{T})$, 'Fascinato'/'Terrano' (F/T), 'Fascinato/Robusto' (F/R) and 'Sweet'/'Robusto' (S/R). Data are means.

the five grafted cultivars $(\mathrm{O} / \mathrm{T}, \mathrm{J} / \mathrm{T}, \mathrm{F} / \mathrm{T}, \mathrm{F} / \mathrm{R}$ and $\mathrm{S} / \mathrm{R})$, during the moths of July to September.

These variables (total $\mathrm{Chl}$ and SPAD values) did not shown an important effect by the type of scion utilized ('Orangela' 'Fascinato', 'Jannette' and 'Sweet'), indicating than all the genotypes had higher levels in these photosynthetic parameters and similar behavior under the shade level utilized ( $38 \%$ of shade). It is important to mention than the 'Fascinato' genotypes had a small increased in the concentration of total Chl.

Grafted bell pepper cultivars (F/T and J/T) attained higher relative leaf Chl. content (SPAD values) and total Chl concentration, which correlations with the highest fruit yield (Fig. 1) and NR activity (Fig. 3). We observed this behavior principally with grafted 'Fascinato' (F/T) cultivar, which had the highest crop yield (Fig. 1). These results coincident with the reported by others authors, than the combination of techniques such as the use of grafted plants and their growth in greenhouse with new thermal photoselective sheets improvement of leaf photosynthesis and increase yield of bell pepper cultivars 
(Basile et al., 2012). However, it will be important to establish the separated effect of these technologies in further studies.

In the total Chl. results, there was significant difference derived from the statistical analysis and SPAD values, between grafted $(\mathrm{F} / \mathrm{T}$ and $\mathrm{J} / \mathrm{T})$ and un-grafted ( $\mathrm{F}$ and $\mathrm{J}$ ) bell pepper cultivars $(\mathrm{p} \leq 0.05)$, studied during the moths of fruit production.

Plant $\mathrm{NO}_{3}$-accumulation is not only affected by the genetic background of the plant, but also by the environmental conditions. The uptake, translocation and assimilation process of nitrate absorbed by the roots and available for translocation are interdependent processes rigorously regulated by the plant and are affected by external conditions such as light and temperature. It considered than combination of techniques such as grafted plants and new agricultural photoselective net can increase yield of bell pepper cultivars under semi-arid conditions (Basile et al., 2012). (Basile et al., 2012). Growth in an agricultural net provides the proper shading/irradiation ratio to create the basic condition for successful pepper development (Bertamini et al., 2006; Zhu et al., 2012). This parameter must have high control because photosynthetic activity is reduced by photoinhibition, due to absorbing excessive light energy of photosynthetic apparatus. Predominantly, high irradiance can cause the inactivation or damage of the chlorophyll-containing reaction centers of the chloroplasts (Bertamini et al., 2006; Zhu et al., 2012). As demonstrate on similar pepper varieties, we found than grafted bell peppers plants attained greatest relative leaf $\mathrm{Chl}$ content (expressed as SPAD value) and total $\mathrm{Chl}$ levels when cultivated with sunshade net, resulting in a high fruit yield.

Today, shading technology is widely used to reduce the problem related with high temperature and high radiation during the summer months of pepper cultivation. Appropriate shading not only improved plants fruit production relative to plants in full sunlight (especially under drought stress), but also increased pigment density per unit leaf areas to optimize effectiveness of light absorption (Wittmann et al., 2001; Dai et al., 2009; Zhu et al., 2012). Therefore, the improvement of leaf photosynthesis by thermal photoselective technology increase potentially yields in pepper crops, during the full fruit-growing stages. Our results provide compelling evidence for the positive effect of grafted rootstock, growth in a greenhouse with white sunshade net, on both the efficient $\mathrm{N}$ use of grafted pepper plants and also the improve of bell pepper yield. This behavior was found more evident with grafted Fascinato cultivar $(\mathrm{F} / \mathrm{T})$, this grafted plant had the adequate characteristics required for commercial bell pepper crop, which are cultivated under this semi-arid conditions.

Another physiological parameters evaluated in this study was total $\mathrm{N}$ concentration (expressed as percent of total $\mathrm{N}$ ) in leaf tissue of grafted bell pepper plants, during the months of fruit production (Fig. 4, Panel C). Leaf $\mathrm{N}$ concentration was not significantly different in grafted plants, during the moths of fruit production ( $p \leq 0.05)$. This fact agreed with the previous findings about the use of rootstocks. Grafted plants usually had lower $\mathrm{N}$ and $\mathrm{NO}_{3}{ }^{-}$ levels in leaf tissue, indicating that these parameters are significantly influenced by the scion-rootstock interaction and by the rootstock (Ruiz et al., 2006; Del Amor et al., 2008). Although we did not detect significant differences in the levels of leaf $\mathrm{N}$ between grafted plants, it is clear than this situation did not produce a negative affected in the $\mathrm{N}$ metabolism and crop yield of these cultivars. Actually, the analysis of biochemistry markers of efficient $\mathrm{N}$ use indicate than the use of rootstocks stimulated the activity of NR and $\mathrm{N}$ metabolism in grafted cultivar.

\section{CONCLUSIONS}

The results of the present study reveal differences between cultivar/rootstock combinations for nitrogen use efficiency and yield. The greatest $\mathrm{N}$ assimilation was presented with the combination Fascinato/Robusto, which coincided with the maximum yield of all cultivar/ roostock combinations evaluated. Hence grafting bell pepper plants can be used as a quick and effective method to improve NUE, which has beneficial implications for a reduction in environmental pollution and agricultural sustainability.

\section{ACKNOWLEDGEMENTS}

This research was supported by the Project 6117 "Evaluación de la marchitez del chile provocada por el hongo phytophthora capsici en portainjertos de la variedad pimiento morrón (Capsicum Annuum) en la región CentroSur del estado de Chihuahua. Fase III", which was financed by CONACyT, grant 2013. Number 153648 .

\section{Author's contributions}

All authors contributed extensively to the work presented in this article. M.L.G.B. and E.S.: Designed and performed research, wrote and revised the manuscript. A.A.G.B.: Contributed to revise the manuscript. E.M.M. and D.L.O.B.: Performed chemical analyses and reviewed the manuscript. J.M.S.P.: Performed statistical analysis and helped in data interpretation and discussion. All authors read and approved the final manuscript. 


\section{REFERENCES}

Arao, T., H. Takeda and E. Nishihara. 2008. Reduction of cadmium translocation from roots to shoots in eggplant (Solanum melongena) by grafting onto Solanumm torvum rootstock. Soil Sci. Plant Nutr. 54: 555-559.

Association of Official Analytical Chemist. 2000. Oficial Methods of Analysis, 17th ed. AOAC International, Guithersbur, MD, p. 52.

Baker, W. H. and T. L. Thompson. 1992. Determination of total nitrogen in plant samples by Kjeldahl. Plant analysis reference procedures for the Southern region of the United States. South. Cooperative Ser. Bull. 368: 13-16.

Basile, B., M. Giacconea, C. Cirillo, A. Ritieni, G. Grazianib, Y. Shahakc and M. Forlania. 2012. Photo-selective hail nets affect fruit size and quality in Hayward kiwifruit. Sci. Hortic. 141: 91-97.

Bertamini, M., K. Muthuchelian and N. Nedunchezhian. 2006. Shade effect alters leaf pigments and photosynthetic responses in Norway spruce (Picea abies L.) Grown under field conditions. Photosynthetica. 2: 227-234.

Chang, S.K.C. 1998. In: Nielsen, S (Ed.), Horticultural Reviews, Aspen Publishers, Gaithersburg, MD, pp. 237-250.

Chávez-Mendoza, C., E. Sánchez, E. Carvajal-Milán, E. Muñoz-Márquez and A. Guevara-Aguilar. 2013. Characterization of the nutraceutical quality and antioxidant activity in bell pepper in response to grafting. Molecules. 18: 15689-15703.

Chávez-Mendoza, C., E. Sánchez, E. Muñoz-Márquez, J. P. Sida-Arreola and M. A. Flores-Córdova. 2015. Bioactive compounds and antioxidant activity in different grafted varieties of bell pepper. Antioxidants. 4: 427-446.

Colla, G., Y. Rouphael, C. Mirabelli and M. Cardarelli. 2011. Nitrogen-use efficiency traits of mini-watermelon in response to grafting and nitrogen-fertilization doses. J. Plant Nutr. Soil Sci. 174: 933-941.

Colla, G., Y. Rouphael, M. Cardarelli, D. Massa, A. Salerno and E. Rea. 2006. Yield, fruit quality and mineral composition of grafted melon plants grown under saline conditions. J. Hortic. Sci. Biotech. 81(1): 146-152.

Colla, G., C.M.C. Suárez, M. Cardarelli and Y. Rouphael. 2010. Improving nitrogen use efficiency in melon by grafting. Hortic. Sci. 45(4): 559-565.

Dai, Y. J., Z. G. Shen, Y. Liu, L. L. Wang, D. Hannawayc and H. F. Lu. 2009. Effects of shade treatments on the photosynthetic capacity, chlorophyll fluorescence, and chlorophyll content of Tetrastigma hemsleyanum Diels et Gilg. Environ. Exp. Bot. 65: 177-182.

De Charlo, H. C. O., S. F. Oliveira, P. F. Vargas, R. Cstoldi, J. C. Barbosa and L. T. Braz. 2012. Accumulation of nutrients in sweet peppers cultivated in coconut fiber. Hortic. Bras. 30: 125-131.

Del Amor, F. M. 2007. Yield and fruit quality response of sweet pepper to organic and mineral fertilization. Renew. Agric. Food Syst. 22: 233-238.

Del Amor, F. M., J. Lopez-Marin and A. Gonzalez. 2008. Effect of photoselective sheet and grafting technique on growth, yield, and mineral composition of sweet pepper plants. J. Plant Nutr. 31: 1108-1120.

Djidonou, D., X. Zhao, E. H. Simonne, K. E. Koch and J. E. Erickson. 2013. Yield, water and nitrogen-use efficiency in field-grown, grafted tomatoes. Hortic. Sci. 48(4): 485-492.

Dong, H. H., Y. H. Niu, W. J. Li and D. M. Zhang. 2008. Effects of cotton rootstock on endogenous cytokinins and abscisic acid in xylem sap and leaves in relation to leaf senescence. J. Exp. Bot. 59: 1295-1304.
Du, Y. D., H. X. Cao, S. Q. Liu, X. B. Gu and Y. X. Cao. 2016. Response of yield, quality, water and nitrogen use efficiency of tomato to different levels of water and nitrogen under drip irrigation in Northwestern China. J. Integr. Agric. 15: 60345-60353.

Garcia, P. C., J. M. Ruiz, R. M. Rivero, L. R. López-Lefebre, E. Sánchez and L. Romero. 2002. Is the application of carbendazim harmfull to healthy plants? Evidence of weak phytotoxicity in tobacco. J. Agric. Food Chem. 50: 279-283.

Lee, J. M., C. Kubota, S. J. Tsao, Z. Bie, P. H. Echevarria, L. Morra and M. Oda. 2010. Current status of vegetable grafting: Diffusion, grafting techniques, automation. Sci. Hortic. 127: 93-105.

Lee, J. M. and M. Oda. 2002. Grafting of herbaceous vegetable and ornamental crops. In: Janick, J (Ed.), Horticultural Reviews, John Wiley \& Sons, Inc., Oxford, UK, p. 352.

Leonardi, C. and F. Giuffrida. 2006. Variation of plant growth and macronutrient uptake in grafted tomatoes and eggplants on three different rootstocks. Eur. J. Hortic. Sci. 71: 97-101.

Ling, Q., W. Huang and P. Jarvis. 2011. Use of a SPAD-502 meter to measure leaf chlorophyll concentration in Arabidopsis thaliana. Photosynth. Res. 107: 209-214.

Mascleaux-Daubresse, C., F. Daniel-Vedele, J. Dechorgnat, F. Chardon, L. Gaufichon and A. Susuki. 2010. Nitrogen uptake, assimilation and remobilization in plants: Challenges for sustainable and productive agriculture. Ann. Bot. 105: 1141-1157.

México Calidad Suprema. 2012. Pliego de Condiciones Para el uso de la Marca Oficial México Calidad Suprema en Pimiento Morrón. PC-022-2005. Available from: http://www.mexicocalidad suprema. org/normich.com.mx/mcs.html. [Last accessed on 2016 Jul ???].

Montemurro, F. and M. Diacono. 2016. Towards a better understanding of agronomic efficiency of nitrogen: Assessment and improvement strategies. Agronomy. 6(31): 1-4.

Otani, T. and N. Seike. 2007. Rootstock control of fruit dieldrin concentration in grafted cucumber (Cucumis sativus). J. Pestic. Sci. 32: 235-242.

Proietti, S., Y. Rouphael, G. Colla, M. Cardarelli, M. De Agazio, M. Zacchini, E. Rea, S. Moscatello and A. Battistelli. 2008. Fruit yield or mini-watermelon as affected by grafting and irrigation regimes. J. Sci. Food Agric. 88: 1107-1114.

Pulgar, G., G. Villora, D. A. Moreno and L. Romero. 2000. Improving the mineral nutrition in grafted watermelon plants: Nitrogen metabolism. Biol. Plant. 43(4): 607-609.

Resendiz-Melgar, R. C., E. C. Moreno-Pérez, F. S. D. Castillo, J. E. Rodríguez-Pérez and A. Peña-Lomelí. 2010. Variedades de pimiento morrón manejadas con despunte temprano en dos densidades de población. Rev. Chapingo Ser. Hortic. 16(3): 223-229.

Rivero, R. M., J. M. Ruiz, E. Sánchez and L. Romero. 2003. Does grafting provide tomato plants and advantage against $\mathrm{H}_{2} \mathrm{O}_{2}$ production under conditions of thermal shock? Physiol. Plant. 117:44-50

Rouphael, Y., M. Cardarelli, G. Colla and E. Rea. 2008a. Yield, mineral composition, water relations, and water use efficiency of grafted mini-watermelon plants under deficit irrigation. Hortic. Sci. 43: 730-736.

Ruiz, J. M., R. M. Rivero, L. M. Cervilla, R. Castellano and L. Romero. 2006. Grafting to improve nitrogen-use efficiency traits in tobacco plants. J. Sci. Food Agric. 86: 1014-1021.

Ruiz, J. M. and L. Romero. 1999. Nitrogen efficiency and metabolism in grafted melon plants. Sci. Hortic. 81: 113-123.

Ruiz, J. M. and L. Romero. 1998. Tomato genotype in relation to nitrogen utilization and yield. J. Agric. Food Chem. 46: 4420-4422. 
Sánchez-Chávez, E., R. Barrera-Tovar, E. Muñoz-Márquez, D. L. Ojeda-Barrios and A. Anchondo-Najera. 2011. Efecto del ácido salicílico sobre biomasa, actividad fotosintética, contenido nutricional y productividad del chile jalapeño. Rev. Chapingo Ser. Hortic. 17(1): 63-68.

Savvas, D., D. Papastavrou, G. Ntasti, A. Ropokis, C. Olympios, H. Hartmann and D. Schwartz. 2009. Interactive effects of grafting and manganese supply on growth, yield, and nutrient uptake by tomato. Hortic. Sci. 44: 1978-1982.

Selahle, K. M., D. Sivakumar, J. Jifon and P. Soundy. 2015. Postharvest responses of red and yellow sweet peppers grown under photo-selective nets. Food Chem. 173: 951-956.

Venema, J. H., B. E. Dijk, J. M. Bax, P. R. Van Hasselt and J. T. M. Elzenga. 2008. Grafting tomato (Solanum lycopersicum) onto the rootstock of a high-altitude accession of Solanum habrochaites improves suboptimal temperature tolerance. Environ. Exp. Bot. 63: 359-367.

Wellburn, A. R. 1994. The spectral determination of chlorophylls a and $\mathrm{b}$, as well as total carotenoids, using various solvents with spectrophotometers of different resolution. J. Plant Physiol. 144: 307-313.

Wittmann, C., G. Aschan and H. Pfanz. 2001. Leaf and twig photosynthesis of young been (Fagus sylvstica) and aspen (Populus tremula) trees grown under different light regime. Basic Appl. Ecol. 2: 145-154.

Yasuor, H., A. Ben-Gal, U. Yermiyahu, E. Beit-Yannai and S. Cohen. 2013. Nitrogen management of greenhouse pepper production: Agronomic, nutritional, and environmental implications. Hortic. Sci. 48(10): 1241-1249.

Yetisir, H., M. E. Caliskan, S. Soylu, and M. Sakar. 2006. Some physiological and growth responses of watermelon [Citrullus lanatus (Trumb.) Matsum and Nakai] grafted onto Lagenaria siceraria to flooding. Environ. Exp. Bot. 58: 1-8.

Zhu, J. J., Q. Peng, Y. L. Liang, X. Wu and W. L. Hao. 2012. Leaf gas exchange, chlorophyll fluorescence, and fruit yield in hot pepper (Capsicum annuum L.) Grown under different shade and soil moisture during the fruit growth stage. J. Integr. Agric. 11: 927-937. 